\title{
ПСИХОДІАГНОСТИЧНІ МЕТОДИКИ ДЛЯ ДІТЕЙ І3 ПОРУШЕННЯМИ ЗОРУ: АДАПТАЦІЯ ТА МОДИФІКАЦІЯ
}

Тетяна Костенко, Інститут спеціальної педагогіки і психології імені Миколи Ярмаченка Національної академії педагогічних наук України м. Київ, Україна, tanya_t.k@ukr.net

Висвітлено проблему діагностики дітей із порушеннями зору, що пов'язана зі специфікою підготовки діагностичного матеріалу індивідуально для кожної дитини залежно від зорового діагнозу. Визначено важливе значення адаптації (модифікації) діагностичного матеріалу в контексті якісного та ефективного навчання дітей із порушеннями зору як у спеціальних закладах так і загальноосвітніх з інклюзивною формою навчання. Проаналізовано стан діючих, стан розроблення та адаптації (модиффікації) діагностичних методик в закладах освіти на сьогодні. Піднято питання розроблення єдиного переліку діагностичних методик обстеження дітей 3 різною патологією зору 3 відповідними вимогами та рекомендаціями. Запропоновано вимоги до стимульного матеріалу методик, до організації і проведення обстеження дітей із порушеннями зору, представлено пам'ятку особливостей зорового приймання при порушеннях зору, яку можна використовувати не лише при проведенні діагностики, а й під час написання висновків та рекомендацій.

Ключові слова: психодіагностика, методики, діти 3 порушеннями зору, модифрікація, адаптація.

Татьяна Костенко, Институт специальной педагогики и психологии имени Николая Ярмаченка Национальной академии педагогических наук Украины, г. Киев, Украина, tanya_t.k@ukr.net

\section{Психодиагностические методики для детей с нарушениями зрения: адаптация и модификация}

Освещена проблема диагностики детей с нарушениями зрения, что связанную со спецификой подготовки диагностического материала индивидуально для каждого ребенка в зависимости от зрительного диагноза. Определены важное значение адаптации (модификации) диагностического материала в контексте качественного и эффективного обучения детей с нарушениями зрения как в специальных заведениях так и общеобразовательных с инклюзивным форме обучения. Проанализировано состояние действующих, состояние разработки и адаптации (модификации) диагностических методик в учебных заведениях на данном этапе. Поднят вопрос разработки единого перечня диагностических методик обследования детей с различной патологией зрения c соответствующими требованиями и рекомендациями. Предложено требования $\mathrm{k}$ стимульного материала методик, к организации и проведению обследования детей с нарушениями зрения, представлены памятник особенностей зрительного приема при (๑) Костенко Т., 2019 
нарушениях зрения, которую можно использовать не только при проведении диагностики, но и при написании выводов и рекомендаций.

Ключевые слова: психодиагностика, методики, дети с нарушениями зрения, модификация, адаптация.

Tetyana Kostenko, Mykola Yarmachenko Institute of Special Education and Psychology of National Academy of Educational Sciences of Ukraine Kyiv, Ukraine tanya_t.k@ukr.net Psychodiagnostic methods for children with visual disorders: adaptation and modification Nowadays modern psychodiagnostic of children with special educational needs actively implemented in inclusive resource centers where a comprehensive psychological and pedagogical assessment of the child's development is the end result of the assessment process and determines the further optimal educational route of the child, including blind and visual impaired. However, the psychodiagnostic of children with visual impairments require special (adapted/modified) techniques that allow children to be examined taking into account visual deprivation. The issue concerning the problem of diagnosing children with visual impairments, which is related to the specificity of preparing the diagnostic material individually for each child, depending on the visual diagnosis is highlighted. The importance of adaptation (modification) of the diagnostic material in the context of qualitative and effective education of children with visual impairments in both specialized institutions and general educational institutions with an inclusive form of study is outlined. The author analyzes the state of existing, state of development and adaptation (modification) of diagnostic methods in educational institutions at this stage. The author raises the issue of the development of the only list of diagnostic methods of examination children with different pathology of vision with appropriate requirements and recommendations. Requirements are given for the stimulating material of the methods, for the organization and examination children with visual impairment, the features of visual acceptance for visual impairment are presented, which can be used not only in diagnostics but also in writing conclusions and recommendations.

Keywords: psychodiagnostic, methods, children with visual impairment, modification, adaptation.

Необхідність проєктування оптимальної освітньої траєкторії дітей з порушеннями зору в умовах навчальних закладів обумовлює високу значущість вчасного та високопрофесійного обстеження особливостей іх розвитку. Нині активно впроваджується сучасна психодіагностика дітей з особливими освітніми потребами в інклюзивно-ресурсні центри, де комплексна психолого-педагогічна оцінка розвитку дитини є кінцевим результатом процесу оцінювання та визначає подальший оптимальний освітній маршрут дитини, зокрема незрячої та 3 порушеннями зору. Проте, проведення психодіагностики дітей із порушеннями зору потребує спеціальних (адаптованих/модифікованих) методик, які дадуть змогу проводити обстеження дітей з врахуванням зорової депривації.

Адаптація передбачає подачу матеріалу методики у формі, доступній для дітей із порушеннями зору, без зміни змісту чи концептуальної складності діагностичного завдання. Адаптація діагностичного матеріалу для незрячих дітей обумовлена іх пізнавальними можливостями, специфікою дотиково-слухового способу сприймання і пізнання навколишньої дійсності, недостатньою сформованістю

«ОСОБЛИВА ДИТИНА: навчання і виховання», № 4, 2019 
предметно-просторових уявлень, своєрідністю методичних прийомів. Адаптація діагностичних методик - це заміна графічного матеріалу, який не сприймається на дотик, текстовими позначеннями, рельєфно-графічними зображеннями чи описовими конструкціями; - перерозподіл складного схематичного чи текстового матеріалу (таблиці, завдання), що перешкоджає цілісному сприйманню незрячих дітей, на менші блоки, без зміни загального змістового наповнення.

При обстеженні можуть бути використані стандартні діагностичні методики, але вони мають відповідати затвердженим вимогам до зорових та тактильних можливостей дітей із порушеннями зору. Тому, поряд з адаптацією (модифікацією) діагностичного матеріалу для дітей з порушеннями зору постає питання з розробки єдиного переліку діагностичних методик обстеження дітей із різною патологією зору з відповідними вимогами та рекомендаціями.

Сьогодні в закладах освіти де навчаються діти з порушеннями зору, фахівці використовуються загальні методики оцінки розвитку дітей, які модифікуються для дітей із порушеннями зору. Наприклад, методики спрямовані на визначення: відхилення у розвитку пізнавальної діяльності у дітей для подальшої їх корекції та контролю над змінами (Е. Підколзіна «Тифлопедагогічна діагностика дошкільників з порушенням зору»); виявлення сформованості таких якостей психічної діяльності, як довільність, сприйняття (величина, форма, колір, просторові відносини), здатність створювати ціле з частин, здатність робити узагальнення, у ході обстеження встановлюється також побутовий і соціальний досвід дітей (С. Забрамна, О. Боровик. «Від діагностики до розвитку»); дослідження тільки пізнавальної сфери дітей (Н. Семаго, М. Семаго «Дослідження особливостей розвитку пізнавальної сфери дітей дошкільного віку»); визначення рівня пізнавального та мовленнєвого розвитку дітей дошкільного віку (Є. Стребелєва. «Психолого-педагогічна діагностика розвитку дітей раннього та дошкільного віку») та ін. [4]. Розроблені та модифіковані методики діагностики психологічної готовності дітей з порушеннями зору до навчання О. Таран; методики вивчення пізнавальної активності дітей із порушеннями зору Т. Костенко, де авторами предстевлені вимоги до діагностичного матеріалу для роботи з дітьми з даною нозологією.

Модифікація психодіагностичних методик передбачає полегшений та зрозумілий для сприйняття текст (відповідно до сформованих уявлень дітьми 3 порушеннями зору). Як варіант модифікації, можливо розробити аудіоверсію текстового діагностичного матеріалу.

Акцентуємо увагу на тому, що не лише успішність навчання, а й соціальна адаптація дитини з порушеннями зору залежить від правильної оцінки можливостей і особливостей ї̈ розвитку[2]. Тому, виходячи з даної ситуації, колективом авторів відділу освіти дітей із порушеннями зору розробляється навчально-методичний посібник: «Особистісно орієнтовані технології навчання дітей 3 порушеннями зору в загальноосвітньому просторі», де будуть представлені рекомендації та вимоги до адаптації (модифікаціі) діагностичного матеріалу для дітей із порушеннями зору. 


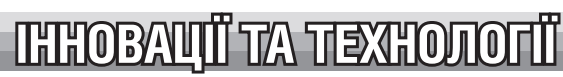

Так, стимульний матеріал для обстеження дітей із порушеннями зору повинен ураховувати індивідуальні особливості й труднощі сприймання матеріалу кожною дитиною. Пропоновані для обстеження завдання можуть складатися з реальних об'єктів, геометричних площинних і об'ємних форм, рельєфних і площинних зображень у контурному або силуетному вигляді, виконаних у різній колірній гаммі [5].

Загальні вимоги до організації і проведення обстеження дітей із порушеннями зору передбачають: організацію попереднього знайомства з історією розвитку дитини, спостереження за поведінкою і діяльністю дитини, встановлення контакту з дитиною до початку обстеження, організації місця, вибору методик.

Спеціальні вимоги передбачають: створення відповідної освітленості (загальна освітленість приміщення повинна становити 1000 лк., на робочому столі дитини - 400-500 лк.); обмеження безперервного зорового навантаження (5 10 хв молодша і середня група, 15 - 20 хв старша група; встановлення режиму зорової роботи лікарем-офтальмологом відповідно до діагнозу й характеру захворювання дитини.

Основними вимогами до характеру стимульного матеріалу є наступні: контрастність пропонованих об'єктів і зображень відносно до фону має бути $60-$ 100 \%; діти краще розрізняють чорні об'єкти на білому фоні, ніж білі об'єкти на чорному; пропорційність співвідношень предметів за величиною відповідно до співвідношеннями реальних об'єктів; співвідношення з реальним кольором об'єктів; високий колірний контраст ( $80-95 \%)$; чітке виділення ближнього, середнього, далекого планів.

Величину пропонованих об'єктів визначають залежно від віку та зорових можливостей дитини, які уточнюються спільно з лікарем-офтальмологом. Відстань від очей дитини до стимульного матеріалу не повинна перевищувати 30-33 cм, а для дітей із глибокими порушеннями зору - залежно від гостроти залишкового зору. Розмір перцептивного поля запропонованих малюнків має становити від 0,5 до $50^{\circ}$. Кутові розміри зображень - у межах $3-35^{\circ}$. Фон має бути розвантажений від деталей, що не входять до завдання (особливо це стосується завдань для дітей дошкільного віку). У колірній гамі бажано використовувати жовто-червоно-оранжеві й зелені тони. Насиченість кольору - 0,8 - 1,0.

Вимоги до стимульного матеріалу та організації діагностичної процедури при обстеженні дітей з амбліопією і косоокістю.

Дітям з амбліопією і косоокістю при гостроті зору до 0,3 рекомендується пропонувати зображення в оранжевих, червоних і зелених тонах без відтінків, 3 високою колірною насиченістю й контрастністю щодо фону.

Розмір пропонованих об'єктів має бути більше 2 см. Показувати можна предмети будь-яких форм - як площинні, так і об'ємні.

При цьому об'ємні предмети бажано пропонувати не тільки для зорового, а й для дотикового обстеження.

Дітям з гостротою зору від 0,4 і вище пропонуються різноманітні за кольором тест-об'єкти з розмірами також близько 2 см (або менше).

«ОСОБЛИВА ДИТИНА: навчання і виховання», № 4, 2019 
Варто пам'ятати, що при збіжній косоокості з далекозорою рефракцією дитині потрібні окуляри.

При розбіжній косоокості та високому ступені міопії також потрібні_окуляри, а при міопії середнього і слабкого ступеня окуляри не потрібні.

Дітям з амбліопією і косоокістю з візусом до 0,3 з нецентральною, але стійкої фіксацією рекомендується пред’являти тест-об'єкти з розмірами більше 2 см переважно помаранчевого, червоного і зеленого кольорів. Форми об'єктів обстежуються і зорово, і дотиково.

Дітям 3 гостротою зору від 0,4 і вище з центральною стійкою фіксацією i з монокулярним і одночасним характером зору, зі збіжною косоокістю можна пред’являти різноманітні об'єкти різних кольорів і розмірів.

Особливість цієї категорії дітей - труднощі конвергенції, релаксації (розслаблення). У них виникають труднощі і з сприйманням об'ємних предметів, а також зображень переднього і заднього плану. Для роботи з стимульним матеріалом у процесі обстеження дітям необхідні окуляри і вправи на розслаблення конвергенції (напрям погляду вгору і вдалину) [1].

Дітям 3 центральною стійкою фіксацією і $з$ монокулярним і одночасним характером зору, але з розбіжною косоокістю можна показувати об'єкти різних кольорів і розмірів.

Дітям з візусом від 0,4 до 1,0 при одночасному бінокулярному нестійкому характері зору й відсутності косоокості пред’явлення стимульного матеріалу супроводжується лише віковими протипоказаннями.

Час, що відводиться дитині для розглядання діагностичного матеріалу i осмислення завдань, має бути збільшений удвічі (а в деяких випадках, наприклад, якщо у дитини дуже низький зір, і в кілька разів більше), ніж у нормі.

Виконання завдань, побудованих на мовному матеріалі, передбачає попередню перевірку розуміння дітьми значення використовуваних слів, висловів, їх відповідності реальним уявленням.

У випадках необхідності проводиться роз'яснювальна робота 3 демонстрацією тих предметів, іграшок, явищ, про які йдеться в завданнях.

Для психолога та фахівців, які обстежуватимуть дитину з порушеннями зору пропонуємо пам'ятку особливостей зорового приймання при порушеннях зору, яку можна також можна використовувати при написанні висновків та рекомендацій.

\begin{tabular}{|l|l|l|}
\hline \multicolumn{1}{|c|}{ Порушення зору } & \multicolumn{1}{|c|}{ Труднощі сприймання } & \multicolumn{1}{c|}{ Стратегії підтримки } \\
\hline Міопія & Не бачить предмети на & Наблизити предмет до очей \\
(короткозорість) & далекій відстані, при & (використання підставок). \\
промені світла входячи & поганому освітленні. & Збільшення контрастності і виділення \\
в око фокусуються & пажко переводить погляд 3 & контурів (підмалювати зображення \\
перед сітківкою & близької відстані вдалечінь & $\begin{array}{l}\text { об'єктів, обвести контури чорним } \\
\text { фломастером). }\end{array}$ \\
& & Забезпечити рівень освітленості. \\
& & 3більшити час розглядання \\
\hline
\end{tabular}




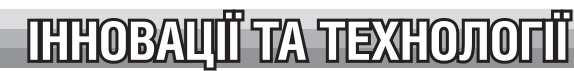

\begin{tabular}{|c|c|c|}
\hline $\begin{array}{l}\text { Гіперметропія } \\
\text { (далекозорість) } \\
\text { промені світла входячи } \\
\text { в око фокусуються за } \\
\text { сітківкою }\end{array}$ & $\begin{array}{l}\text { Утруднене сприймання } \\
\text { об'єктів на близькій відстані, } \\
\text { дрібних предметів чи } \\
\text { деталей }\end{array}$ & $\begin{array}{l}\text { Віддалити об'єкт сприймання від очей. } \\
\text { Збільшити дрібні деталі, виділити їх. } \\
\text { Збільшення міжрядкових відстаней }\end{array}$ \\
\hline Астигматизм & $\begin{array}{l}\text { Зображення не збирається в } \\
\text { одному фокусі }\end{array}$ & $\begin{array}{l}\text { Залучати до сприймання дотик, } \\
\text { (рельєфні об'єкти), інші види відчуттів }\end{array}$ \\
\hline $\begin{array}{l}\text { Порушення окорухових } \\
\text { функцій (косоокість, } \\
\text { ністагм) }\end{array}$ & $\begin{array}{l}\text { Не може сфрокусувати } \\
\text { погляд на об'єкті, } \\
\text { порушений бінокулярний } \\
\text { зір, зниження просторового } \\
\text { синтезу та цілісності } \\
\text { сприймання, сприймання } \\
\text { сповільнене, утруднене } \\
\text { сприймання об'єктів, що } \\
\text { рухаються. } \\
\text { Різна гострота зору на очах } \\
\text { (амбліопія) }\end{array}$ & $\begin{array}{l}\text { Збільшити час розглядання об’єктів. } \\
\text { Використовувати рельєфну наочність. } \\
\text { Тренування навичок бінокулярного зору }\end{array}$ \\
\hline $\begin{array}{l}\text { Афракія } \\
\text { (відсутність кришталика) }\end{array}$ & $\begin{array}{l}\text { Неможливість сприймання } \\
\text { при слабкому освітленні, } \\
\text { сповільнене сприймання } \\
\end{array}$ & $\begin{array}{l}\text { Добре освітлити об'єкт. } \\
\text { Збільшити час сприймання }\end{array}$ \\
\hline $\begin{array}{l}\text { Атрофія зорового нерва } \\
\text { (дегенерація волокон } \\
\text { зорового нерва, які } \\
\text { передають інформацію } \\
\text { від сітківки до мозку) }\end{array}$ & $\begin{array}{l}\text { Складно розрізнювати світлі } \\
\text { об'єкти на світлому тлі } \\
\text { Труднощі впізнавання } \\
\text { предметів } \\
\text { Труднощі збереження } \\
\text { зображення у фокусі }\end{array}$ & $\begin{array}{l}\text { Використовувати темні зображення на } \\
\text { світлому тлі. } \\
\text { Забезпечення візуальної стимуляції для } \\
\text { поліпшення здатності сприймати зорову } \\
\text { інфрормацію }\end{array}$ \\
\hline Альбінізм & $\begin{array}{l}\text { Зниження гостроти зору, } \\
\text { надмірна чутливість до } \\
\text { світла, ністагм }\end{array}$ & $\begin{array}{l}\text { Уникання прямого сонячного світла в } \\
\text { робочій зоні. } \\
\text { Використання збільшувальних засобів. } \\
\text { Збільшення часу на виконання завдання } \\
\end{array}$ \\
\hline $\begin{array}{l}\text { Амбліопія (зниження } \\
\text { гостроти зору на } \\
\text { одному оці) }\end{array}$ & $\begin{array}{l}\text { Дитина використовує лише } \\
\text { одне око (яке краще бачить) } \\
\text { замість обох. Порушується } \\
\text { бінокулярність зору } \\
\text { Труднощі при письмі та } \\
\text { читанні } \\
\end{array}$ & $\begin{array}{l}\text { Використання оклюзії (закривання ока } \\
\text { яке краще бачить) для тренування } \\
\text { «лінивого ока» (на якому зір } \\
\text { знижений) } 3 \text { допомогою різних зорових } \\
\text { навантажень: обведення контурів } \\
\text { малюнків, читання дрібного шрифрту } \\
\end{array}$ \\
\hline Катаракта & $\begin{array}{l}\text { Зниження гостроти зору } \\
\text { і «затуманення» або } \\
\text { виключення частини } \\
\text { зорового сприймання, } \\
\text { особливо в яскравому світлі. } \\
\text { Ускладнене розрізнення } \\
\text { кольорів } \\
\end{array}$ & $\begin{array}{l}\text { Збільшити час на розглядання } \\
\text { навчального матеріалу, освітлити робочу } \\
\text { зону }\end{array}$ \\
\hline $\begin{array}{l}\text { Глаукома (збільшення } \\
\text { внутрішньочного } \\
\text { тиску, призводить до } \\
\text { пошкодження зорового } \\
\text { нерву) }\end{array}$ & $\begin{array}{l}\text { Зниження гостроти та втрата } \\
\text { периферичного зору. } \\
\text { Дитина має труднощі } 3 \\
\text { орієнтуванням. Важко } \\
\text { переводити погляд між } \\
\text { близькими та далекими } \\
\text { об'єктами }\end{array}$ & $\begin{array}{l}\text { Дотримання режиму зорового } \\
\text { навантаження. } \\
\text { Зосередити необхідну зорову роботу в } \\
\text { близькій зоні. } \\
\text { Сприймання на мультисенсорній основі }\end{array}$ \\
\hline
\end{tabular}

«ОСОБЛИВА ДИТИНА: навчання і виховання», № 4, 2019 


\begin{tabular}{|c|c|c|}
\hline Дегенерація сітківки & $\begin{array}{l}\text { Поступова втрата } \\
\text { центрального зору. } \\
\text { Труднощі ідентифікації } \\
\text { зображень. } \\
\text { Труднощі розрізнення світлих } \\
\text { предметів на темному фоні. } \\
\text { Труднощі читання тексту на } \\
\text { дошці або сторінці }\end{array}$ & $\begin{array}{l}\text { Збільшити розмір тексту, контрастність. } \\
\text { При прогресуючих станах - } \\
\text { мінімізовувати зорові навантаження, } \\
\text { розвивати навички дотикового } \\
\text { сприймання, словесно підкріплювати } \\
\text { процес сприймання }\end{array}$ \\
\hline Пігментний ретиніт & $\begin{array}{l}\text { Зниження периферичного } \\
\text { та сутінкового зору. } \\
\text { При зниженні освітлення } \\
\text { фактично втрачає } \\
\text { можливість бачити } \\
\text { Виникають труднощі } 3 \\
\text { мобільністю, сприйманням } \\
\text { простору та читанням текстів } \\
\text { на дошці або в книжці }\end{array}$ & $\begin{array}{l}\text { Забезпечити додаткове освітлення. } \\
\text { Збільшити розмір тексту та наочності }\end{array}$ \\
\hline
\end{tabular}

Отже, проведення психологічної діагностики дітей із порушеннями зору вимагає спеціальних або адаптованих методик. Адаптація стимульного матеріалу при дослідженні дітей із порушеннями зору зумовлена необхідністю його чіткого і точного сприйняття дітьми і потребує від фахівця знання діагнозу захворювання і стану основних зорових функцій дитини 3 порушеннями зору. Під час обстеження можуть бути використані стандартизовані діагностичні методики для визначення рівня розумового розвитку та навчальної діяльності дітей із порушеннями зору. Однак це можливо лише за наявності умов, що дають змогу дітям вирішувати ці завдання, а саме, при адаптації матеріалу відповідно до загальних вимог до зорових і тактильних можливостям дітей 3 порушеннями зору.

\section{ЛITEPATУPA}

1. Ермаков В. П., Якунин Г. А. Основы тифлопедагогики: развитие, обучение и воспитание детей с нарушениями зрения / В .П. Ермаков, Г. А. Якунин. - М.: Владос, 2000. - 119 с.

2. Клопота $C$. А. Особливості процесу інтеграції в суспільство осіб з глибокими порушеннями зору / Є. А. Клопота // Актуальні проблеми навчання та виховання людей з особливими потребами. - 2015. - № 12 (14). - С. 142-155.

3. Кобильченко В. В. Спеціальна психологія на сучасному історичному етапі: пошук власної наукової ідентичності // Журнал «Педагогіка і психологія». - 2016. - № 2. - С. 64-70.

4. Костенко T. М. Розробка програми корекції розвитку з глибокими порушеннями зору : емоційно-вольова сфера. / Проблеми сучасного підручника: зб. наук. праць / [ред.кол.; голов. ред. - О. М. Топузов]. К: Педагогічна думка. 2016. - Вип.12. - С. 208-215.

5. Кульбіда С. В. Освіта XXI століття. Дефектологія. № 2. 2006. С. 54 - 56.

\section{REFERENCES (TRANSLATED AND TRANSLITERATED)}

1. Ermakov V. P., Jakunin G. A. (2000). Osnovy tiflopedagogiki: Razvitie, obuchenie i vospitanie detej s narushenijami zrenija. Moskva: Vlados. [In Russian]. 
2. Klopota Ye. A. (2015). Osoblyvosti protsesu intehratsii v suspilstvo osib z hlybokymy porushenniamy zoru. Aktualni problemy navchannia ta vykhovannia liudei z osoblyvymy potrebam 12(14). [In Ukrainian].

3. Kobylchenko V. V. (2016). Spetsialna psykholohiia na suchasnomu istorychnomu etapi: poshuk vlasnoi naukovoi identychnosti. Zhurnal "Pedahohika i psykholohiia" (2) [In Ukrainian].

4. Kostenko T. M. (2016). Rozrobka prohramy korektsii rozvytku z hlybokymy porushenniamy zoru : emotsiino-volova sfera. Problemy suchasnoho pidruchnyka: zbirnyk naukovykh prats. Kyiv: Pedahohichna dumka (12).

5. Kulbida S. V. (2006). Osvita KhKhI stolittia. Defektolohiia. № 2. 2006. S. $54-56$. 